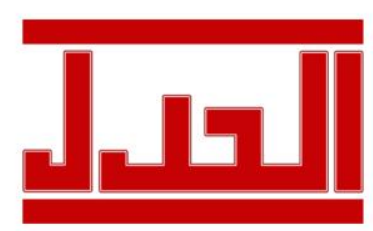

ISSN: $1979-4940$

E-ISSN : 2477-0124
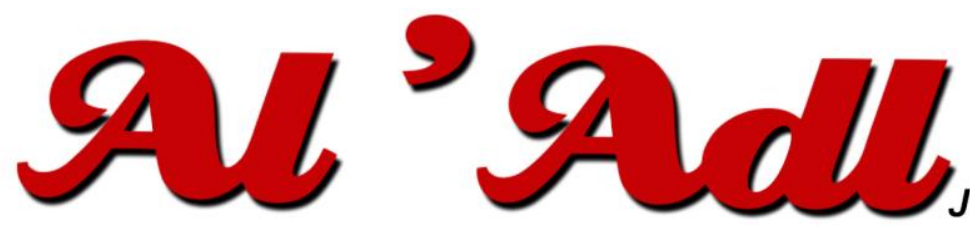

Jurnal Hukum

Editorial Office: Faculty of Law, Islamic University Of Kalimantan,

Jalan Adhyaksa No. 2 Kayutangi Banjarmasin, Kalimantan Selatan, Indonesia (70123)

Email: al_adl@uniska-bjm.ac.id

Web: http://ojs.uniska-bjm.ac.id

\title{
DISGORGEMENT: PEMULIHAN KERUGIAN INVESTOR PASAR MODAL (STUDI KOMPARASI AMERIKA SERIKAT DAN INDONESIA)
}

\author{
${ }^{[1]}$ Vania Regina Artemisia Wijaya* \& ${ }^{[2]}$ Ariawan Gunadi \\ Fakultas Hukum Universitas Tarumanagara \\ Jl. S. Parman No. 1, Jakarta Barat 11440, Indonesia \\ E-mail: ${ }^{[1]}$ vania.205180050@stu.untar.ac.id \\ [2] ariawang@fh.untar.ac.id
}

*Corresponding author

$\begin{array}{ll}\text { Submitted } & : \text { 7 Desember 2021 } \\ \text { Revised } & : \text { 1 Januari 2022 } \\ \text { Accepted } & : \text { 9 Januari 2022 } \\ \text { Published } & : \text { 18 Januari 2022 }\end{array}$

Jurnal Al Adl by Universitas Islam Kalimantan Muhammad Arsyad albanjari is licensed under a Creative Commons Attribution 4.0 International License. (CC-BY)

\begin{abstract}
An investor is the most foremost party in capital market activities. However, in the event of a violation of capital market regulations committed by an irresponsible party, an investor often experiences in a disadvantaged position due to the lack of legal protection for the investor. At the end of 2020, OJK took an initiative to adopt a disgorgement mechanism which belongs to the United States by issuing POJK Number 65 / POJK.04 / 2020 , aiming to increase the guarantee of investor protection in transacting in the capital market by providing compensation funds if the investors are loss-making due to violations, and strive for creating deterrent effects to prevent the occurrence of other violations. This research focuses on comparing the concepts and mechanisms of disgorgement applied in the United States and Indonesia, hopefully, the results are expected to be an input for OJK in implementing disgorgement in concrete cases in Indonesia. The method used was normative legal research with conceptual approach, legislation, and comparison. After having done this research, the results revealed that the disgorgement mechanism is a form of legal protection needed by Indonesian capital market investors today, yet in terms of the arrangement, there are still several things that need to be evaluated and developed by the OJK so that when applied in the future, the goal of adopting disgorgement to provide legal protection for investors and become a preventive effort to violation can be achieved.
\end{abstract}

Keywords: Disgorgement; Capital Market; Legal Protection; Investor.

\section{Abstrak}

Investor merupakan pihak yang sangat penting dalam aktivitas pasar modal. Namun, dalam hal terjadi pelanggaran peraturan pasar modal yang dilakukan oleh pihak tidak bertanggung jawab, investor kerap kali ditempatkan pada posisi yang kurang menguntungkan sebagai akibat dari minimnya perlindungan hukum terhadapnya. Pada akhir tahun 2020, OJK mengambil inisiatif mengadopsi mekanisme disgorgement milik Amerika Serikat dengan menerbitkan POJK Nomor 65/POJK.04/2020 yang bertujuan meningkatkan terjaminnya perlindungan investor dalam bertransaksi di pasar modal dengan memberikan dana kompensasi apabila mengalami kerugian akibat pelanggaran dan mengusahakan terciptanya efek jera sehingga tidak terjadi pelanggaran lagi. Adapun penelitian ini berfokus pada komparasi konsep dan mekanisme disgorgement yang diterapkan di Amerika Serikat dan Indonesia yang hasilnya diharapkan dapat menjadi masukan bagi OJK dalam mengimplementasikan disgorgement dalam kasus konkret di Indonesia. Dalam penelitian ini digunakan 
penelitian hukum normatif dan digunakan pendekatan konseptual, perundang-undangan, dan perbandingan. Setelah dilakukan penelitian, diperoleh hasil bahwa mekanisme disgorgement merupakan bentuk perlindungan hukum yang dibutuhkan oleh investor pasar modal Indonesia saat ini namun dalam pengaturannya masih terdapat beberapa hal yang perlu dievaluasi dan dikembangkan lagi oleh OJK agar saat diterapkan kelak tujuan dari pengadopsian disgorgement untuk memberikan perlindungan hukum investor dan menjadi upaya preventif pelanggaran dapat tercapai.

Kata kunci: Disgorgement; Pasar Modal; Perlindungan Hukum; Investor.

\section{PENDAHULUAN}

Batas teritorial antarnegara menjadi semakin samar bahkan hilang seiring pesatnya arus globalisasi. Hal ini berdampak secara langsung terhadap perekonomian nasional tiap-tiap negara sehingga timbul kompetisi untuk mewujudkan kondisi ekonomi yang mampu menopang keberlangsungan negaranya serta meningkatkan taraf hidup rakyatnya. Oleh karena itu, negara sebagai entitas harus membangun perekonomian yang berimbang dan berkelanjutan dalam pelbagai sektor, tidak terkecuali sektor pasar modal. Pada setiap negara, pasar modal memiliki peran penting sebagai wadah pengalokasian dana yang efisien dan efektif yang bertujuan mendapatkan keuntungan optimal di waktu yang akan datang. Pasar modal merupakan kegiatan jual beli sekuritas yang berusia lebih dari 1 (satu) tahun (long term investment) dengan diselenggarakannya perjumpaan pihak surplus modal dengan pihak defisit modal. ${ }^{1}$

Bersamaan dengan makin berkembangnya pengetahuan dan mudahnya akses untuk memperoleh informasi mengenai pasar modal, inventor Indonesia mengalami peningkatan yang tajam beberapa waktu terakhir. Data PT Kustodian Sentral Efek Indonesia menunjukkan jumlah investor yang menyentuh angka lebih dari 6,29 juta Single Investor Identification (SID) per 30 September 2021 yang artinya terdapat peningkatan sebesar $61,86 \%$ dibandingkan penghujung tahun $2020 .^{2}$ Akan tetapi, peningkatan ini tidak menghilangkan realita bahwa pasar modal Indonesia tidak dapat lepas dari praktik pelanggaran yang dapat mendatangkan kerugian bagi berbagai pihak terutama investor. Sebagai contoh beberapa kasus besar diantaranya kasus PT Sarijaya Permana Sekuritas yang merugikan 8.700 nasabahnya dengan angka kerugian sebesar Rp. 235 miliar, kasus PT Antaboga Delta Sekuritas yang merugikan investor senilai Rp. 1,4 triliun, dan kasus PT Andalan Artha Advisindo Sekuritas yang merugikan investor sebesar Rp. 120 miliar. Hingga saat ini, korban

${ }^{1}$ Eduardus Tandelilin, (2017), Pasar Modal: Manajemen Portofolio dan Investasi, Yogyakarta: PT Kanisius, hlm. 25.

2 Ika Puspitasari, "Investor Pasar Modal Mencapai 6,29 Juta per September 2021", https://investasi.kontan.co.id/news/investor-pasar-modal-mencapai-629-juta-per-september-2021 (diakses pada tanggal 5 Desember 2021 pukul 00.36 WIB). 
dalam kasus-kasus tersebut belum memperoleh kompensasi yang sepadan dengan kerugian yang mereka alami. ${ }^{3}$

Pada dasarnya, Pemerintah Indonesia sudah mengupayakan perlindungan hukum investor melalui Undang-Undang Republik Indonesia Nomor 8 Tahun 1995 tentang Pasar Modal (UU PM) yang mengatur pelanggaran administratif dan pidana pasar modal. Namun, sanksi terhadap pelanggaran tersebut hanya berupa sanksi administratif, pidana penjara, dan denda sehingga sama sekali tidak memberikan kompensasi bagi investor. ${ }^{4}$ Meskipun tidak ada kompensasi yang diberikan secara langsung oleh pemerintah, investor dapat mengajukan ganti kerugian melalui jalur litigasi perdata dengan melayangkan gugatan perbuatan melawan hukum (onrechtmatige daad) berdasarkan Pasal 111 UU PM. ${ }^{5}$ Namun demikian jalur litigasi bukan merupakan pilihan terbaik karena tidak efektif dan efisien dalam penyelesaiannya dan tidak ada kepastian seluruh kerugian investor akan dikembalikan secara utuh.

Selain melalui gugatan perdata, OJK juga berupaya melindungi kepentingan investor yang dirugikan dengan menerbitkan POJK Nomor 49/POJK.04/2016 tentang Dana Perlindungan Pemodal (POJK 49/POJK.04/2016). Namun, cakupan perlindungan DPP hanya terbatas pada kerugian investor akibat fraud yang mengakibatkan investor kehilangan asetnya di bank kustodian atau perusahaan efek dan tidak mengganti kerugian akibat tindak pidana pasar modal. ${ }^{6}$ Selain itu, berdasarkan POJK tersebut investor hanya dapat memperoleh ganti kerugian maksimal Rp. 100.000.000,00 (seratus juta rupiah). Akan tetapi, jumlah ini mengalami peningkatkan sejak tanggal 23 Desember 2020 dengan dikeluarkannya Keputusan OJK No. Kep-69/D.04/2020 menjadi Rp. 200.000.000,00 (dua ratus juta rupiah). Kekosongan perlindungan hukum yang diatur bagi investor menjadikan dana atau aset yang diletakkan oleh investor di pasar modal tidak terjamin pemulihannya apabila mereka menjadi korban pelanggaran.

Padahal pemulihan kerugian sangat fundamental dalam upaya melindungi investor. Amerika Serikat sebagai kiblat pasar modal dunia sudah menerapkan praktik pemulihan kerugian investor sejak 1971 melalui mekanisme disgorgement yang dijalankan oleh Securities and Exchange Commision (SEC). Disgorgement adalah "the act of giving up

\footnotetext{
${ }^{3}$ Mochamad Januar Rizki, "OJK Segera Atur Soal Ganti Rugi Investor Akibat Kejahatan Pasar Modal”, https://www.hukumonline.com/berita/baca/lt5c6a92e5f2588/ojk-segera-atur-soal-ganti-rugi-investor-akibatkejahatan-pasar-modal, (diakses pada tanggal 5 Desember 2021 pukul 00.39 WIB).

${ }^{4}$ Nikmah Mentari, (2021), "Disgorgement (Fund): New Era of Investor Protection in the Capital Market", Journal of Indonesian Law, Volume 2, Nomor 1, 2021, hlm. 108.

${ }^{5}$ Undang-Undang Republik Indonesia Nomor 8 Tahun 1995 tentang Pasar Modal, Pasal 111.

6 Dyah Ayu Purboningtyas dan Adya Prabandari, (2019), "Perlindungan Hukum Bagi Investor Pasar Modal Indonesia oleh Securities Investor Protection Fund”, Jurnal Notarius, Volume 12 Nomor 2, hlm. 806.
} 
something (such as profits illegally obtained) on demand or by legal compulsion" ", yang berarti kegiatan mengembalikan sesuatu (seperti profit yang diperoleh secara tidak sah) terhadap perintah permintaan atau paksaan hukum. Dalam hal ini, SEC diberikan oleh undang-undang pasar modal Amerika Serikat bertujuan mengakomodasi keadilan bagi investor dengan meminta secara paksa pelaku pelanggaran mengembalikan keuntungan yang didapatkannya secara tidak sah atau illegal agar tidak dapat dinikmati oleh pelanggar.

Berkaca dari Amerika Serikat, OJK kemudian mengtransplantasi konsep disgorgement tersebut dengan mengeluarkan POJK Nomor 65/POJK.04/2020 tentang Pengembalian Keuntungan Tidak Sah dan Dana Kompensasi Kerugian Investor di Bidang Pasar Modal (POJK 65/POJK.04/2020) dan aturan turunannya yaitu Surat Edaran Otoritas Jasa Keuangan (SEOJK) Nomor 17/SEOJK.04/2021 tentang Pengembalian Keuntungan Tidak Sah dan Dana Kompensasi Kerugian Investor di Bidang Pasar Modal (SEOJK Nomor 17/SEOJK.04/2021). Namun, OJK melakukan penyesuaian nomenklatur dimana disgorgement dikenal sebagai Pengembalian Keuntungan Tidak Sah (PKTS) dan disgorgement fund sebagai Dana Kompensasi Kerugian Investor (DKKI).

Walaupun OJK sudah menetapkan ketentuan pasti mengenai hal tersebut, konsep disgorgement dan disgorgement fund sebagai bentuk perlindungan hukum investor yang masih sangat baru di Indonesia. Maka dari itu, muncul skeptis bahwa hal ini melahirkan persoalan saat diterapkan kelak. Lebih lagi, Indonesia mengacu pada konsep disgorgement dan disgorgement fund yang diimplementasikan di Amerika Serikat maka perlu disesuaikan dengan system hukum di Indonesia akibat adanya disparitas sistem hukum dengan Amerika Serikat. Oleh karena itu, sangat penting untuk melakukan komparasi dengan Amerika Serikat sebagai referensi pada tataran praktiknya di Indonesia dalam penanganan kasus pelanggaran pasar modal dan memberikan perlindungan hukum yang optimal bagi investor.

\section{RUMUSAN MASALAH}

Berdasarkan paparan latar belakang di atas, identifikasi permasalahan yang diangkat adalah bagaimana perbandingan mekanisme disgorgement dalam memberikan perlindungan hukum investor pasar modal Amerika Serikat dan Indonesia dalam memenuhi aspek perlindungan hukum investor pasar modal? hlm. 1410 .

${ }^{7}$ Bryan A. Garner, (2004), Black's Law Dictionary $8^{\text {th }}$ Edition, Amerika Serikat: West Publishing Co., 


\section{TUJUAN PENELITIAN}

Penelitian ini bertujuan mengkomparasi mekanisme disgorgement yang diterapkan di Amerika Serikat dan Indonesia untuk mengembangkan mekanisme disgorgement yang diimplementasikan di Indonesia melalui POJK 65/POJK.04/2020 agar lebih baik dalam penerapannya di kasus konkret pasar modal kelak.

\section{METODE PENELITIAN}

Peneliti menggunakan metode penelitian hukum normatif, yakni penelitian yang mengambil isu dari hukum sebagai sistem norma untuk memberikan keadilan. ${ }^{8}$ Dalam penelitian ini digunakan pendekatan konseptual (conpceptual approach) mengacu pada pendapat dan/atau doktrin yang berhubungan dengan hukum ${ }^{9}$, pendekatan perundangundangan (statute approach) menganalisis seluruh aturan dengan melihat relevansinya dengan permasalahan yang saat ini sedang dicari jawabannya ${ }^{10}$, dan pendekatan perbandingan (comparative approach) dengan mengkaji persamaan dan perbedaan antarnegara. ${ }^{11}$ Ketiganya dikombinasikan untuk memecahkan isu hukum yang diangkat dengan menggunakan ketentuan di bidang pasar modal, meneliti konsep disgorgement sebagai pemulihan kerugian investor akibat pelanggaran di bidang pasar modal, dan melakukan perbandingan pengaturan dengan Amerika Serikat.

Teknik studi kepustakaan (library research) akan dimanfaatkan untuk memecahkan masalah dalam penelitian ini. Selanjutnya, jenis data beserta sumber-sumber penelitiannya dirincikan menjadi beberapa tingkatan berupa bahan hukum primer, sekunder, dan tersier. ${ }^{12}$ Pertama, jenis data bahan hukum primer yang sifatnya mengatur sebagai sumber utama terdiri atas peraturan perundang-undangan serta putusan pengadilan yang relevan. Kedua, bahan hukum sekunder sebagai pendukung mencakup buku dan jurnal hukum baik cetak maupun elektronik sepanjang mempunyai relevansi dengan apa yang sedang diteliti. ${ }^{13}$ Ketiga, bahan hukum tersier sebagai pelengkap yang menyediakan definisi dan gambaran mengenai hal yang kurang terang berupa kamus hukum.

\footnotetext{
8 Mukti Fajar dan Yulianto Ahmad, (2017), Dualisme Penelitian Hukum Normatif \& Empiris, Yogyakarta: Pustaka Pelajar, hlm. 54.

${ }^{9}$ Peter Mahmud Marzuki, (2013), Penelitian Hukum: Edisi Revisi, Cetakan ke-8, Jakarta: Kencana Prenada Media Group, hlm. 135.

${ }^{10}$ Ibid., hlm. 133.

${ }^{11}$ Ibid., hlm. 176.

${ }^{12}$ Ibid., hlm. 181.

${ }^{13}$ Ibid., hlm. 195-196.
} 


\section{PEMBAHASAN}

Pada Desember 2020 OJK melakukan inovasi melalui penerbitan POJK 65/POJK.04/2020 yang bertujuan memberikan kepastian perlindungan bagi investor agar tercipta rasa aman saat berinvestasi. Inovasi OJK ini sebagaimana disampaikan oleh Hoesen, Kepala Eksekutif Pengawas Pasar Modal OJK, bercermin dari mekanisme perlindungan investor milik Amerika Serikat. ${ }^{14}$ Di sana, lembaga otoritas pasar modalnya, SEC, berwenang memaksa para pelanggar peraturan pasar modal untuk melakukan pengembalian keuntungan yang dihasilkan dari kejahatan yang nantinya akan digunakan untuk membayar kompensasi bagi investor. Namun demikian, terlepas dari keoptimisan OJK perlu dilakukan tinjauan lebih jauh mengingat Indonesia dan Amerika Serikat memiliki perbedaan sistem hukum. Yurisprudensi merupakan sumber hukum utama di Amerika Serikat, sedangkan sumber hukum Indonesia bertumpu pada hukum yang terkodifikasi. ${ }^{15}$ Adanya pertentangan sistem hukum mendorong perlunya dilakukan kajian lebih jauh terkait pengaturan dan implementasi mekanisme disgorgement. Maka dari itu, peneliti akan menguraikan perbandingannya antara Amerika Serikat dan Indonesia sebagai berikut.

1. Konsep disgorgement

Amerika Serikat telah menerapkan disgorgement sejak 1971 dengan pergeseran konsep berdasarkan putusan Mahkamah Agung yang mendasarinya. Gagasan awal SEC dalam menerapkan disgorgement adalah kasus Texas Gulf Sulphur Co. v. SEC di mana pengadilan menyimpulkan bahwa disgorgement merupakan equitable remedy atau pemulihan yang adil. Kemudian pada tahun 1990, Kongres Amerika Serikat menegaskan kembali disgorgement sebagai equitable remedy melalui Security Enforcement Remedies Penny Stock Reform Act 1990 dan sejak saat itu SEC selalu berupaya melaksanakan mekanisme disgorgement, khususnya dalam kasus penipuan sekuritas dan perdagangan orang dalam. ${ }^{16}$

Pada tahun 2017, Mahkamah Agung Amerika Serikat melalui putusan Kokesh v. SEC memutuskan bahwa disgorgement diberlakukan dengan konsep penalty sehingga tunduk pada Statute of Limitation of 28 U.S.C. $\$ 2462$ yang didasarkan pada 3 (tiga)

\footnotetext{
${ }^{14}$ Hendri Tri Widi Asworo, (2021), "Belajar dari Kasus Jiwasraya, OJK Siapkan Denda Hingga 300 Persen", $\quad$ https://finansial.bisnis.com/read/20200215/215/1201961/belajar-dari-kasus-jiwasraya-ojk-siapkandenda-hingga-300-persen, (diakses pada 3 November 2021 pukul 11.58 WIB). 28.

${ }^{15}$ Soerojo Wignjodipoero, (1983), Pengantar dan Asas-Asas Hukum Adat, Jakarta: Gunung Agung, hlm.

16 Uni Tri Sulastri, (2020), "Disgorgement as Remedial Action in Indonesian Capital Market Regime", Jurnal Hukum Novelty, Volume 11, Issue 1, 2020, hlm. 6.
} 
prinsip, yaitu penegakkan disgorgement oleh SEC dimaksudkan untuk memperbaiki keadaan publik, bukan memberi kompensasi kepada korban secara individu; disgorgement dijatuhkan untuk menghukum karena pada dasarnya sanksi yang bertujuan untuk memberikan efek jera secara inheren adalah hukuman; dan pelanggar seringkali berada di posisi yang lebih buruk karena penentuan jumlah disgorgement melebihi keuntungan ilegalnya. ${ }^{17}$

Seiring bertambahnya kasus pelanggaran pasar modal, Amerika Serikat sebagai negara yang menganut sistem hukum Anglo Saxon, menetapkan norma baru dalam penerapan disgorgement dengan mengubah konsep penalty menjadi equitable remedy terbatas melalui putusan Liu et al. v. SEC pada tahun 2020 dengan syarat bahwa disgorgement fund wajib didistribusikan pada korban pelanggaran yang dalam hal ini adalah investor pasar modal, perintah disgorgement hanya dapat dikenai pada seorang pelanggar dan tidak dapat dikenai pada beberapa orang pelanggar atau afiliasinya, dan disgorgement terbatas pada keuntungan bersih yang diperoleh pelanggar sehingga harta kekayaan pelanggar harus dikurangi terlebih dahulu dengan biaya pengeluaran yang sah. ${ }^{18}$ Oleh karena itu, hakikat disgorgement adalah perbaikan dengan mengembalikan keuntungan pelanggar kepada investor yang dirugikan haknya. ${ }^{19}$

Dalam menerapkan disgorgement, Indonesia menganut konsep remedial action atau aksi remedial dengan prinsip penalty setting. Dalam POJK 65/POJK.04/2020 tidak terdapat penjelasan lebih lanjut mengenai remedial action dan penalty setting. Sedangkan di dalam Penjelasan RPOJK Disgorgement dan Disgorgement Fund disebutkan bahwa, "Disgorgement sebagai suatu remedial action diharapkan dapat mencegah Pihak yang melakukan pelanggaran menikmati keuntungan yang diperolehnya secara ilegal, mengkompensasi kerugian dari korban pelanggaran, mengandung unsur korektif, dan diharapkan dapat memberikan efek jera". Apabila dilihat dari penjelasan tersebut, sebenarnya sudah tercermin mekanisme disgorgement yang diterapkan berdasarkan POJK 65/POJK.04/2020 meskipun tidak secara eksplisit diatur di dalamnya. Pada dasarnya, disgorgement Indonesia yang menganut konsep remedial action dengan prinsip penalty setting tidak memiliki perbedaan yang berarti dengan konsep equitable remedy

17 Jacqueline K. Chang, (2018), "Kokesh v. SEC: The Demise of Disgorgement", North Carolina Banking Institute, Volume 22 Issue 1, hlm. 314.

18 Avi Weitzman dan Tina Samanta, (2020), "Liu v SEC: Supreme Court Cabins SEC Disgorgement Remedy", Securities in the Electronic Age Wall Street Lawyer, Volume 24, Issue 7, hlm. 3.

19 Alan R. Friedman et al., (2020), "Liu v. S.E.C.: Supreme Court's narrowing of SEC disgorgement raises questions for insider trading cases", Journal of Investment Compliance, hlm. 3. 
yang diterapkan di Amerika Serikat karena substansi penting keduanya adalah kompensasi bagi investor yang menderita kerugian. Namun yang menjadi pokok perbedaannya adalah konsep equitable remedy berfokus pada pemulihan kerugian korban dan bukan sebagai upaya penghukuman untuk tujuan preventif. Selain itu, perbedaan sistem hukum di antara Amerika Serikat dan Indonesia juga memberikan pengaruh besar terhadap perbedaan pengaturan dan penerapan konsep disgorgement karena dalam implementasinya harus disesuaikan dengan keadaan masyarakat setempat agar dapat melahirkan budaya hukum sesuai dengan yang diharapkan. Maka dari itu, apabila melihat pada konsep disgorgement yang sudah berjalan di Amerika Serikat sejak lama, OJK dapat melakukan kajian dan evaluasi lebih lanjut mengenai konsep disgorgement yang paling tepat bagi Indonesia.

2. Otoritas dalam menetapkan disgorgement

SEC sebagai lembaga pengatur, pengawas, dan penegak hukum pasar modal di Amerika Serikat telah diberikan kewenangan secara eksplisit untuk mengklaim perintah disgorgement, yakni diatur dalam Section 8A (e) Securities Act of 1933, Section 21 (3)(A) dan Section 21 (d) (5) Securities Exchange Act of 1934, yang pada pokoknya menyatakan bahwa SEC dapat mengajukan klaim atau gugatan disgorgement dan bunga yang wajar terhadap para pelanggar hukum pasar modal dan dapat dikabulkan oleh pengadilan federal. Lebih lanjut diatur dalam Rules of Practice yang lebih dari setengah ketentuannya mengatur mengenai prosedur SEC dalam mengeluarkan perintah disgorgement yang dimulai dari inisiasi sidang, persiapan dengar pendapat, dengar pendapat ${ }^{20}$, pengajuan banding terhadap keputusan $\mathrm{SEC}^{21}$, serta setiap perintah dan penangguhan sementara. ${ }^{22}$

Dalam penjatuhan disgorgement, SEC dapat menempuh jalur sidang perdata dan sidang administratif. ${ }^{23}$ Sidang perdata diawali dengan SEC yang mengajukan gugatan perdata terhadap pelanggar hukum pasar modal, pengadilan distrik dapat menjatuhkan sanksi denda atau memerintahkan keuntungan ilegalnya dikembalikan. Berbeda dengan langkah sidang perdata, sidang administratif merupakan sidang yang dapat dipimpin sendiri oleh SEC maupun didelegasikan kewenangannya kepada Administratie Law

${ }^{20}$ Rules of Practice and Rules on Fair Fund and Disgorgement Plans September 2019, Rules 200-360.

${ }^{21}$ Ibid., Rules 400-490.

${ }^{22}$ Ibid., Rules 500-550.

23 U.S. Securities and Exchange Commission, (2021), "How Investigations Work", https://www.sec.gov/enforce/how-investigations-work.html, (diakses pada tanggal 5 Desember 2021 pukul 01.14 WIB). 
Judge (ALJ) sebagai komisi independen. Berdasarkan bukti-bukti yang diajukan oleh staf divisi SEC, ALJ melakukan dengar pendapat dan mempertimbangkannya untuk menjatuhkan putusan awal yang memuat temuan fakta, kesimpulan hukum, dan rekomendasi sanksi bagi pelanggar. Kemudian terhadap putusan awal tersebut, staf divisi SEC dan pelaku pelanggaran dapat mengajukan banding dan SEC dapat menguatkan putusan ALJ, membalikkan putusan, atau memerintahkan pemeriksaan tambahan.

Di Indonesia, kewenangan OJK dalam menetapkan disgorgement berdasar pada Pasal 9 huruf d UU OJK ${ }^{24}$ memiliki kewenangan untuk memberikan perintah tertulis sesuai kewenangan pengaturan dan mengenakan kepada pihak di sektor jasa keuangan sesuai dengan kewenangan pengawasan. Pasal tersebut merupakan satu-satunya aturan yang melandasi OJK secara eksplisit dalam menerbitkan perintah disgorgement bagi pelanggar peraturan perundang-undangan di bidang pasar modal, berbeda dengan Amerika Serikat yang menyatakan kewenangan SEC secara eksplisit dalam beberapa aturan yang mendasarinya.

Dalam penjatuhan disgorgement, OJK dapat mengeluarkan perintah tersebut berdasarkan kewenangannya sendiri bersamaan dengan dijatuhkannya sanksi administratif sehingga tidak perlu mengajukan gugatan perdata kepada pengadilan dan menunggu putusan pengadilan. Namun demikian, dalam POJK 65/POJK.04/2020 dan SEOJK Nomor 17/SEOJK.04/2021 sama sekali tidak terdapat penjelasan mengenai prosedur penetapan disgorgement oleh OJK. Apabila meninjau pengaturan dan penerapan disgorgement di Amerika Serikat, jelas terdapat aturan mengenai prosedur penerbitan perintah disgorgement oleh SEC dalam Rules 200-550 Rules of Practice. Sedangkan di Indonesia prosedur penetapan perintah disgorgement merupakan mekanisme internal yang dilakukan OJK setelah mengetahui adanya indikasi kuat pelanggaran pasar modal dengan pedoman umumnya sebagaimana diatur dalam POJK Nomor 36/POJK.04/2018 tentang Tata Cara Pemeriksaan di Sektor Pasar Modal.

Berkaitan dengan perbedaan mekanisme yang dilakukan sebelum penetapan disgorgement, meskipun terdapat perbedaan sistem hukum yang saling bertentangan di antara keduanya, Indonesia melalui OJK dapat bercermin kepada Amerika Serikat yang mengatur prosedurnya secara transparan sehingga dapat diakses dan diketahui oleh semua

${ }^{24}$ Lihat konsiderans POJK Nomor 65/POJK.04/2020 tentang Pengembalian Keuntungan Tidak Sah dan Dana Kompensasi Kerugian Investor di Bidang Pasar Modal. 
pihak demi memenuhi aspek kepastian hukum dan keadilan sebagaimana yang diharapkan.

3. Ruang lingkup pemberlakuan disgorgement

Umumnya, SEC melakukan investigasi terhadap jenis-jenis pelanggaran untuk mengajukan disgorgement seperti informasi efek penting yang salah atau keliru, manipulasi harga efek di bursa, mencuri dana atau efek investor, melanggar tanggung jawab broker dan dealer dalam bersikap adil pada investor, perdagangan orang dalam, dan penjualan efek yang tidak terdaftar. ${ }^{25}$ Sebelum mengajukan gugatan perdata untuk meminta penjatuhan perintah disgorgement baik melalui sidang perdata atau sidang administratif, SEC melakukan investigasi tertutup untuk memperoleh bukti kemungkinan pelanggaran undang-undang pasar modal dari berbagai sumber, meliputi penyelidikan formal, memeriksa saksi, memeriksa catatan pialang, meninjau data perdagangan efek, dan lain sebagainya. SEC dapat mengajukan klaim disgorgement dari setiap keuntungan ilegal yang didapatkan oleh pihak yang melanggar ketentuan hukum dan melakukan kejahatan pasar modal. ${ }^{26}$

Di Indonesia, ruang lingkup pemberlakuan disgorgement diatur dalam Pasal 2 Ayat (1) POJK 65/POJK.04/2020, disgorgement dikenakan terhadap Pihak yang melakukan dan/atau Pihak yang menyebabkan terjadinya pelanggaran peraturan perundang-undangan di bidang pasar modal. Pelanggaran dalam konteks ini sangat luas dan kurang jelas cakupannya karena terdiri atas pelanggaran administratif, pelanggaran teknis, dan pelanggaran pidana termasuk di dalamnya kejahatan pasar modal. Namun apabila mengacu pada konsep dasar disgorgement, maka dapat disimpulkan bahwa bentuk pelanggaran yang dapat dikenakan disgorgement adalah pelanggaran yang menghasilkan keuntungan tidak sah atau kerugian yang dihindari.

Di Indonesia, sering kali pelanggaran pidana pasar modal ditemukan indikasinya di dalam tindak pidana lain yang sedang diperiksa baik di tingkat penyidikan maupun persidangan hal suatu kasus telah dilanjutkan ke tahap penyidikan kemudian ditemukan adanya pelanggaran pidana pasar modal, OJK berharap ke depannya Indonesia dapat menjalankan prosedur yang sudah diterapkan di Amerika Serikat yaitu perintah

25 U.S. Securities and Exchange Commission, (2021), "How Investigations Work", https://www.sec.gov/enforce/how-investigations-work.html, diakses pada tanggal 5 Desember 2021 pukul 01.40 WIB.

${ }^{26}$ Howard Chitimira, (2012), "A Comparative Analysis of The Enforcement of Market Abuse Provisions", Disertasi, Faculty of Law Nelson Mandela Metropolitan University, hlm. 226. 
penetapan disgorgement dapat disertakan dalam surat tuntutan penuntut umum untuk nantinya ditetapkan juga dalam amar putusan hakim. ${ }^{27}$ Hal ini relevan untuk diterapkan di Indonesia mengingat seringkali indikasi tindak pidana pasar modal ditemukan dalam kasus tindak pidana lain yang sedang berjalan proses penanganannya sehingga para penegak hukum cenderung mengabaikan tindak pidana pasar modal yang dilakukan ditambah lagi pembuktiannya yang sangat sulit.

4. Sumber disgorgement fund

Di Amerika Serikat, disgorgement fund dibentuk berdasarkan Section 21F (a) (4) Securities Exchange Act of 1934 dan Rule 1100 Rules of Practice yang pada pokoknya menjelaskan bahwa SEC dapat mengeluarkan perintah yang mensyaratkan pembayaran sanksi moneter yang meliputi denda, disgorgement, bunganya terhadap pelanggar yang didepositokan ke dalam disgorgement fund berdasarkan Section 308 (b) Sarbanes-Oxley Act of 2002. Maka dapat disimpulkan bahwa sumber disgorgement fund selain disgorgement juga termasuk denda dan bunga yang dibayarkan. Berkaitan dengan denda, terdapat 3 (tiga) tingkatan berdasarkan jumlah denda yang dikenai terhadap pelanggar, diantaranya: ${ }^{28}$

a. Tingkat pertama yakni untuk perbuatan yang termasuk dalam pelanggaran ketentuan pasar modal didenda tiap perbuatannya paling tinggi $\$ 9,753$ bagi orang perseorangan dan $\$ 97,523$ untuk subjek hukum lain.

b. Tingkat kedua yakni untuk perbuatan yang termasuk dalam pelanggaran ketentuan pasar modal disertai penipuan, pengecohan, manipulasi, dan pengabaian ketentuan didenda tiap perbuatannya paling tinggi $\$ 97,523$ bagi orang perseorangan dan $\$ 487,616$ bagi subjek hukum lain.

c. Tingkat ketiga yakni untuk perbuatan yang termasuk dalam pelanggaran ketentuan pasar modal disertai penipuan, pengecohan, manipulasi, dan pengabaian ketentuan yang menimbulkan kerugain yang sangat substansial bagi orang lain atau menghasilkan keuntungan besar bagi pelanggar didenda tiap perbuatannya paling tinggi $\$ 195,047$ bagi orang perserorangan dan $\$ 975,230$ bagi subjek hukum lain.

Dengan jumlah denda yang tinggi bagi setiap pelanggar kemudian ditambahkan dengan disgorgement dan bunga yang dibayarkan, disgorgement fund yang nantinya akan

${ }^{27}$ Wawancara dengan Bapak Nurman Cahyadi, S.H., M.H., M.PA. selaku Deputi Direktur Penetapan Sanksi Pasar Modal 1 Otoritas Jasa Keuangan pada tanggal 17 November 2021 melalui media Zoom.

28 U.S. Securities and Exchange Commission, (2021), "Inflation Adjustments to the Civil Monetary Penalties Administered by the Securities and Exchange Commission (as of January 15, 2021), https://www.sec.gov/files/civil-penalties-inflation-adjustments.pdf, (diakses pada tanggal 5 Desember 2021 pukul $02.30 \mathrm{WIB})$. 
dibayarkan sebagai pemulihan kerugian investor jumlahnya akan sangat besar dan mampu menutupi seluruh kerugian yang dialami investor pasar modal Amerika Serikat.

Di Indonesia, disgorgement fund hanya bersumber dari pembayaran disgorgement oleh pihak yang melakukan dan/atau menyebabkan terjadinya pelanggaran peraturan perundang-undangan pasar modal. Mengingat sumber dananya bergantung pada kemampuan pihak yang dikenai disgorgement dalam membayar, ini menimbulkan ketidakpastian bagi investor dalam perlindungan hukumnya untuk memperoleh ganti kerugian. Dalam Pasal 10 (1) POJK 65/POJK.04/2020 juga disebutkan bahwa OJK baru dapat membentuk DKKI apabila dana yang dihimpun dinilai fisibel. Fisibilitas disgorgement fund ditentukan dengan mempertimbangkan jumlah disgorgement tertagih, rencana biaya operasional pelaksanaan disgorgement fund, dan identifikasi awal ada tidaknya investor yang merugi. ${ }^{29}$ Apabila dana disgorgement tidak fisibel, maka dana tersebut akan digunakan untuk kepentingan pengembangan industri pasar modal. ${ }^{30}$ Apabila dibandingkan dengan Amerika Serikat yang disgorgement fund-nya berasal dari 3 (tiga) sumber dan sudah pasti dana yang akan terkumpul berjumlah besar. Di Indonesia, terdapat POJK 3/POJK.04/2021 tentang Penyelenggaraan Kegiatan di Bidang Pasar Modal, yang dalam Pasal 98 Ayat (1) mengatur mengenai sanksi denda yang dapat dikenakan pada pelanggar ketentuan peraturan perundang-undangan di bidang pasar modal selain keterlambatan penyampaian laporan atau pengumuman yaitu paling banyak Rp. 5.000.000 (lima juta rupiah) bagi orang perseroangan dan Rp. 25.000.000.000 (dua puluh lima juta rupiah) bagi pihak bukan orang perseorangan. Dalam hal ini, OJK dapat menjadikan Amerika Serikat sebagai acuan guna memperbaiki dan mengembangkan substansi hukum yang telah disusun dengan menambahkan sumber disgorgement fund lain seperti sanksi denda sebagaimana diatur dalam POJK 3/POJK.04/2021 agar dana ganti rugi terjamin fisibilitasnya untuk memenuhi perlindungan hukum investor sekaligus memberikan efek jera bagi pelanggar agar perbuatan tidak terulang kembali.

5. Mekanisme penagihan dan pembayaran disgorgement fund

SEC dalam menetapkan perintah disgorgement berdasarkan Rule 600 harus dengan jelas menyatakan pelanggaran yang menjadi dasar dikenakannya disgorgement, waktu terjadinya tiap-tiap pelanggaran untuk menghitung jumlah disgorgement, jumlah

\footnotetext{
${ }^{29}$ Peraturan Otoritas Jasa Keuangan Republik Indonesia Nomor 65/POJK.04/2020 tentang Pengembalian Keuntungan Tidak Sah dan Dana Kompensasi Kerugian Investor di Bidang Pasar Modal, Pasal 10 Ayat (2).

${ }^{30}$ Ibid., Pasal 10 Ayat (3).
} 
disgorgement untuk setiap pelanggaran, total disgorgement yang harus dibayarkan, pertimbangan pengenaan disgorgement, dan bunga pre-judgment. Berdasarkan perintah disgorgement tersebut, pelanggar yang dikenai harus melakukan pembayaran paling lambat 21 (dua puluh satu) hari sesudah dikeluarkannya perintah tersebut. ${ }^{31)}$ Pembayaran harus dilakukan melalui wesel pos, transfer kawat, cek bersertifikat, cek kasir bank, atau dikirim langsung ke kantor yang telah ditunjuk oleh SEC. ${ }^{32}$

Apabila pihak yang dikenai perintah disgorgement tidak membayar dalam rentang waktu yang ditentukan, pihak tersebut dapat mengajukan bukti ketidakmampuan membayar dengan menunjukkan laporan keuangan paling terakhir yang dijamin kebenarannya dan SEC atau hearing officer dapat memutuskan untuk mengambil langkah lebih lanjut dalam pemberian diskresi. ${ }^{33}$ Namun apabila pihak yang dikenai disgorgement tidak menunjukkan laporan keuangan paling terakhirnya, maka pihak tersebut dianggap telah mengabaikan pengajuan ketidakmampuan membayar. Apabila disgorgement tetap tidak dibayarkan oleh pelanggar, Divisi Penegakan SEC dapat memakai cara-cara yang tersedia untuk melakukan identifikasi, likuidasi, dan mnghimpun aset yang bisa memenuhi tunggakan utang melalui Kantor Penagihan, termasuk memberikan surat permintaan, melakukan negosiasi mengenai rencana pembayaran, melakukan pengajuan hak gadai properti, melakukan pembayaran imbalan, atau mengajukan tindakan penghinaan (contempt action) di pengadilan. ${ }^{34}$ Lebih lanjut, pengadilan dapat menangguhkan atau melarang pelanggar menjabat sebagai direktur perusahaan bahkan menjatuhkan denda tambahan atau pidana penjara karena dianggap telah melanggar perintah pengadilan (contempt of court). ${ }^{35}$

Di Indonesia, perintah pembayaran disgorgement dikeluarkan sendiri oleh OJK dalam bentuk perintah tertulis bersamaan dengan diberlakukannya sanksi administratif terhadap pelanggar peraturan peraturan perundang-undangan pasar modal setelah proses pemeriksaan di internal $\mathrm{OJK}^{36}$. Pelanggar harus melakukan pembayaran paling lambat 30

\footnotetext{
${ }^{31}$ Rules of Practice..., Op. Cit., Rule 601 (a).

${ }^{32}$ Ibid., Rule 601 (b).

${ }^{33}$ Ibid., Rule 630.

${ }^{34}$ U.S. Securities and Exchange Commission, (2021), "Investor Bulletin: How Victims of Securities Law Violations May Recover Money", https://www.sec.gov/oiea/investor-alerts-bulletins/ib_recovermoney.html, (diakses pada tanggal 5 Desember 2021 pukul 02.55 WIB).

${ }^{35}$ U.S. Securities and Exchange Commission, "How Investigations Work", Loc. Cit.

${ }^{36}$ Raysa Mayasonda et al., (2020), "Kajian Terhadap Rencana Pengaturan Digsorgement Dalam Pasar Modal Indonesia", JCH (Jurnal Cendekia Hukum), Volume 6, Nomor 1, hlm. 7.
} 
(tiga puluh) hari setelah diterimanya perintah tersebut. ${ }^{37}$ Jika pihak yang dikenakan disgorgement tidak dapat melakukan pembayaran melalui rekening dana, pembayaran dapat dilakukan dengan menggunakan aset tetap berupa tanah, tanah dan bangunan, dan/atau kendaraan bermotor. ${ }^{38}$ Apabila pihak yang dikenakan disgorgement menolak untuk membayar, OJK memerintahkan pencairan aset dalam rekening Efek dan/atau rekening lain kepada Lembaga Penyimpanan dan Penyelesaian, lembaga jasa keuangan, dan/atau Pihak lain yang terkait, dengan tembusan pihak yang dikenakan disgorgement. ${ }^{39}$ Berkaitan dengan tidak dibayarnya disgorgement oleh pelanggar, OJK dapat memberikan peringatan berbentuk surat teguran sebanyak 2 (dua) kali dengan rentang waktu masingmasing teguran 30 (tiga puluh) hari. ${ }^{40}$ Setelah 2 (dua) kali peringatan, apabila pihak yang diperintahkan untuk membayar disgorgement masih tidak melakukan pembayaran, maka OJK dapat melakukan beberapa tindakan, seperti melanjutkan ke tahap penyidikan, mengajukan gugatan perdata, dan/atau mengajukan permohonan kepailitan. ${ }^{41}$

Jika dibandingkan dengan Amerika Serikat, cara pembayaran disgorgement fund di Indonesia lebih variatif karena terdapat opsi alternatif selain pembayaran dengan dana yaitu dapat menggunakan aset tetap. Selain itu, OJK dapat mengambil tindakan memblokir rekening efek, rekening lainnya, dan/atau pemindahbukuan aset, serta pencairan aset dalam rekening tersebut. Lebih lanjut, tindakan yang dapat dilakukan OJK apabila pelanggar tidak membayar disgorgement lebih luas dibandingkan dengan Amerika Serikat, yakni OJK dapat melanjutkan ke tahap penyidikan, menggugat secara perdata, dan/atau memohon pailit pihak tersebut. Namun, ketiga tindakan ini memunculkan isu baru yang juga menjadi perdebatan tajam di internal OJK yakni tidak efisiennya proses pemulihan kerugian investor karena investor yang seharusnya memperoleh penggantian kerugian dalam waktu yang singkat melalui disgorgement tetap harus menunggu proses penyidikan, litigasi perdata, dan pailit, yang mana sebenarnya dapat dilakukan oleh investor yang merugi sejak awal tanpa melalui prosedur disgorgement ditambah lagi dalam pengajuan pailit OJK tidak ditentukan setingkat Ayat (1)

${ }^{37}$ Peraturan Otoritas Jasa Keuangan Republik Indonesia Nomor 65/POJK.04/2020..., Op. Cit., Pasal 5

${ }^{38}$ Ibid., Pasal 7 Ayat (2) huruf a.

39 Surat Edaran Otoritas Jasa Keuangan Republik Indonesia Nomor 17/SEOJK.04/2021 tentang Pengembalian Keuntungan Tidak Sah dan Dana Kompensasi Kerugian Investor di Bidang Pasar Modal, Romawi V angka 7.

${ }^{40}$ Peraturan Otoritas Jasa Keuangan Republik Indonesia Nomor 65/POJK.04/2020..., Op. Cit., Pasal 5 Ayat (4) dan Ayat (5).

${ }^{41}$ Ibid.., Pasal 9 Ayat (1). 
kreditor preferen yang diutamakan pembayarannya meskipun OJK berharap tagihan disgorgement dapat dipersamakan dengan pajak dan bea cukai yang memiliki hak didahulukan. Oleh karena itu, OJK perlu meninjau kembali tindakan yang tepat dan efisien untuk dilakukan ketika pihak yang diperintahkan disgorgement tidak bersedia membayar seperti mengambil contoh pemberlakuan norma contempt of court dengan penjatuhan denda tambahan atau pidana penjara sebagaimana diterapkan di Amerika Serikat.

6. Distribusi disgorgement fund

Disgorgement fund dibentuk setelah perintah disgorgement dikeluarkan dan dana yang sudah terkumpul sebagaimana diatur dalam Rules 1105 Rules of Practice dikelola oleh SEC dengan mendelegasikan kewenangannya pada pegawai SEC atau pihak lain yang ditunjuk sebagai Administrator. Dalam pendistribusian disgorgement fund, SEC akan mengambil keputusan distribusi dengan mempertimbangkan 2 (dua) faktor, yaitu identifikasi ada tidaknya kelas investor sebagai korban yang merugi dan nominal uang terkumpul dari pelanggar untuk didistribusikan pada sejumlah investor yang berpotensi. ${ }^{42}$ Mekanisme pendistribusian disgorgement fund diawali dengan pengajuan rencana distribusi oleh Divisi Penegakan SEC dalam waktu 60 hari setelah menerima dana dari pelanggar. ${ }^{43}$ Rencana distribusi harus memuat prosedur penagihan pembayaran kepada pelanggar, instrumen yang akan digunakan untuk menyimpan pembayaran, bukti pembayaran pelanggar, spesifikasi kategori investor yang berhak memperoleh disgorgement fund termasuk jumlah kerugian yang dialami, prosedur pemberitahuan eksistensi fair fund dan potensi mendapatkan ganti rugi investor, prosedur untuk mengajukan dan menyetujui klaim termasuk prosedur keberatan terhadap keputusan atas permohonan klaim, batas waktu mengenai pengambilan klaim yang telah disetujui, dan ketentuan lain yang diminta oleh hakim atau SEC. ${ }^{44}$ Selanjutnya adalah pemberitahuan mengenai adanya disgorgement fund kepada masyarakat melalui website SEC dan media lain yang ditetapkan. Pemberitahuan tersebut harus memuat rincian mengenai cara masyarakat memperoleh salinan rencana distribusi. Terhadap pemberitahuan tersebut, masyarakat yang tidak berkepentingan dengan rencana tersebut dapat memberikan

\footnotetext{
${ }^{42}$ Urska Velikonja, (2015), "Public Compensation for Private Harm: Evidence from The SEC's Fair Fund Distribution", Stanford Law Review, Volume 67, Issue 2, hlm. 13.

${ }^{43}$ Rules of Practice..., Op. Cit., Rule 1101 (a).

44) Ibid., Rule 1101 (b).
} 
tanggapan secara tertulis kepada SEC. ${ }^{45}$ Kemudian 30 (tiga puluh) hari setelah pemberitahuan disgorgement fund, SEC harus memberikan keputusan, baik menyetujui, menyetujui dengan perubahan, maupun menolak rencana tersebut. Apabila rencana pendistribusian sudah disetujui oleh SEC, selanjutnya disgorgement fund akan didistribusikan oleh Administrator yang ditunjuk oleh SEC kepada investor yang berhak sesuai kriteria yang tercantum di dalam rencana distribusi tiap-tiap kasus.

Disgorgement fund baru dibentuk oleh OJK sekaligus menunjuk Administrator yang bertugas menyusun rencana distribusi kepada OJK paling lambat 21 (dua puluh satu) hari kerja setelah ditunjuk. ${ }^{46}$ Rencana distribusi tersebut harus memuat latar belakang disgorgement fund, kriteria investor yang berhak mengajukan klaim, tata cara pengajuan klaim, periode pengajuan klaim paling cepat 21 hari dan paling lambat 90 hari, penghitungan jumlah kerugian riil, prosedur pendistribusian dana, biaya pengadministrasian dan pendistribusian dana. ${ }^{47}$ Terhadap rencana distribusi yang disampaikan Administrator, OJK dapat menyetujui dengan atau tanpa perubahan. ${ }^{48}$ Setelah rencana distribusi disetujui, selanjutnya Administrator mengumumkan rencana distribusi pada situs web disgorgement fund. ${ }^{49}$ Setiap pengajuan klaim dari investor harus diverifikasi oleh Administrator ${ }^{50}$ dan setelah diverifikasi, Administrator membuat rencana pembayaran klaim dan menyampaikannya pada OJK paling lambat 5 (lima) hari kerja. ${ }^{51}$ Apabila rencana pembayaran klaim investor disetujui, kemudian OJK memberikan instruksi pada Penyedia Rekening Dana untuk membayar disgorgement fund melalui pemindahbukuan ke rekening dana tiap-tiap investor paling lambat 3 (tiga) hari kerja setelah diinstruksikan. ${ }^{52}$

Berkaitan dengan pendistribusian disgorgement fund, terdapat 2 (dua) ketentuan. Pertama, apabila jumlah disgorgement fund lebih besar dari jumlah klaim investor maka distribusi akan dilakukan sesuai jumlah klaim tiap-tiap investor dan sisanya akan digunakan untuk kepentingan pengembangan industri pasar modal. Kedua, apabila

\footnotetext{
${ }^{45}$ Ibid., Rule 1103.

${ }^{46}$ Peraturan Otoritas Jasa Keuangan Republik Indonesia Nomor 65/POJK.04/2020..., Op. Cit., Pasal 18 Ayat (1).

${ }^{47}$ Ibid., Pasal 17.

${ }^{48}$ Ibid., Pasal 18 Ayat (2).

${ }^{49}$ Ibid., Pasal 19 Ayat (3).

${ }^{50}$ Ibid., Pasal 20 Ayat (1).

${ }^{51}$ Ibid., Pasal 22 Ayat (1).

${ }^{52}$ Ibid., Pasal 22 Ayat (2), Ayat (3), dan Ayat (4).
} 
jumlah disgorgement fund lebih kecil dari jumlah klaim investor maka distribusi akan dilakukan secara proporsional atau pro rata. ${ }^{53}$

Apabila dibandingkan dengan Amerika Serikat, terlihat bahwa pengaturan mengenai mekanisme distribusi disgorgement fund di Indonesia lebih jelas dan rinci walaupun tidak terbuka kesempatan bagi masyarakat untuk ikut memberikan tanggapan atas rencana distribusi yang diumumkan oleh Administrator. Kemudian OJK hanya dapat memberikan persetujuan atau persetujuan dengan perubahan terhadap rencana distribusi yang mana ini lebih efektif dibandingkan dengan SEC yang dapat menolak rencana distribusi sehingga harus menyusun rencana dari awal lagi.

Berkaitan dengan kriteria investor yang berhak memperoleh disgorgement fund, POJK 65/POJK.04/2020 hanya mengatur kriterianya secara negatif yakni disgorgement fund tidak diberikan kepada investor yang sudah menerima kompensasi dari pelanggar atau mengajukan upaya hukum mandiri sebelumnya. Meskipun sudah terdapat 2 (dua) kriteria tersebut, menurut saya OJK perlu mengatur lebih rinci lagi mengenai investor yang berhak mengajukan klaim disgorgement agar tercipta efisiensi waktu daripada harus menunggu diterbitkannya rencana distribusi di situs web Administrator.

\section{PENUTUP}

\section{Kesimpulan}

Berdasarkan paparan hasil dan pembahasan, dapat ditarik kesimpulan bahwa mekanisme disgorgement milik Amerika Serikat yang ditransplantasi oleh Indonesia telah dikaji dan disesuaikan oleh OJK agar relevan dan optimal dalam penerapannya di Indonesia. Disgorgement Indonesia ditegaskan eksistensinya dengan penerbitan POJK Nomor 65/POJK.04/2020 dan SEOJK Nomor 17/SEOJK.04/2021. Kendati demikian sebagai moda perlindungan hukum baru bagi investor di Indonesia, pengaturan mengenai mekanisme disgorgement masih membutuhkan penyempurnaan sebagaimana telah dikomparasi dengan pengaturannya di Amerika Serikat sebagai negara yang sudah menjalankan disgorgement selama 50 tahun demi mencapai tujuan dari pengadopsiannya yakni mencegah pelanggar dapat menikmati keuntungan illegal, memulihkan kerugian investor, dan menjadi langkah preventif terjadinya pelanggaran.

53) Ibid., Pasal 23. 


\section{Saran}

Peneliti memberikan saran pada OJK agar mencanangkan pengaturan disgorgement di tingkat peraturan yang lebih tinggi seperti memasukkannya dalam revisi UU PM atau UU OJK, mengevaluasi dan memperbaiki pengaturan mengenai disgorgement agar perlindungan investor pasar modal menjadi lebih maksimal dan dapat menimbulkan efek jera sehingga meminimalisasi terjadinya pelanggaran pasar modal. 


\section{DAFTAR PUSTAKA}

\section{Buku}

Bryan A. Garner, (2004), Black's Law Dictionary $8^{\text {th }}$ Edition, Amerika Serikat: West Publishing Co.

Eduardus Tandelilin, (2017), Pasar Modal: Manajemen Portofolio dan Investasi, Yogyakarta: PT Kanisius.

Mukti Fajar dan Yulianto Ahmad, (2017), Dualisme Penelitian Hukum Normatif \& Empiris, Yogyakarta: Pustaka Pelajar.

Peter Mahmud Marzuki, (2013), Penelitian Hukum: Edisi Revisi, Cetakan ke-8, Jakarta: Kencana Prenada Media Group.

Soerojo Wignjodipoero, (1983), Pengantar dan Asas-Asas Hukum Adat, Jakarta: Gunung Agung.

\section{Jurnal dan Publikasi Lainnya}

Alan R. Friedman et al., (2020), "Liu v. S.E.C.: Supreme Court's narrowing of SEC disgorgement raises questions for insider trading cases", Journal of Investment Compliance.

Avi Weitzman dan Tina Samanta, (2020), "Liu v SEC: Supreme Court Cabins SEC Disgorgement Remedy", Securities in the Electronic Age Wall Street Lawyer, Volume 24, Issue 7.

Dyah Ayu Purboningtyas dan Adya Prabandari, (2019), "Perlindungan Hukum Bagi Investor Pasar Modal Indonesia oleh Securities Investor Protection Fund", Jurnal Notarius, Volume 12 Nomor 2.

Howard Chitimira, (2012), "A Comparative Analysis of The Enforcement of Market Abuse Provisions", Disertasi, Faculty of Law Nelson Mandela Metropolitan University.

Jacqueline K. Chang, (2018), "Kokesh v. SEC: The Demise of Disgorgement", North Carolina Banking Institute, Volume 22 Issue 1.

Nikmah Mentari, (2021), "Disgorgement (Fund): New Era of Investor Protection in the Capital Market", Journal of Indonesian Law, Volume 2 Nomor 1.

Raysa Mayasonda et al., (2020), "Kajian Terhadap Rencana Pengaturan Digsorgement Dalam Pasar Modal Indonesia”, JCH (Jurnal Cendekia Hukum), Volume 6 Nomor 1.

Uni Tri Sulastri, (2020), "Disgorgement as Remedial Action in Indonesian Capital Market Regime", Jurnal Hukum Novelty, Volume 11 Issue 1.

Urska Velikonja, (2015), "Public Compensation for Private Harm: Evidence from The SEC's Fair Fund Distribution", Stanford Law Review, Volume 67 Issue 2. 


\section{Internet}

Hendri Tri Widi Asworo, (2021), "Belajar dari Kasus Jiwasraya, OJK Siapkan Denda Hingga 300 Persen", https://finansial.bisnis.com/read/20200215/215/1201961/belajardari-kasus-jiwasraya-ojk-siapkan-denda-hingga-300-persen.

Ika Puspitasari, "Investor Pasar Modal Mencapai 6,29 Juta per September 2021", https://investasi.kontan.co.id/news/investor-pasar-modal-mencapai-629-juta-perseptember-2021.

Mochamad Januar Rizki, “OJK Segera Atur Soal Ganti Rugi Investor Akibat Kejahatan Pasar Modal", https://www.hukumonline.com/berita/baca/lt5c6a92e5f2588/ojk-segeraatur-soal-ganti-rugi-investor-akibat-kejahatan-pasar-modal.

U.S. Securities and Exchange Commission, (2021), "How Investigations Work", https://www.sec.gov/enforce/how-investigations-work.html.

---------, (2021), “How Investigations Work", https://www.sec.gov/enforce/howinvestigations-work.html.

-----------, "Inflation Adjustments to the Civil Monetary Penalties Administered by the Securities and Exchange Commission (as of January 15, 2021), https://www.sec.gov/files/civil-penalties-inflation-adjustments.pdf.

-----------, "Investor Bulletin: How Victims of Securities Law Violations May Recover Money", bulletins/ib_recovermoney.html. https://www.sec.gov/oiea/investor-alerts-

\section{Peraturan Perundang-Undangan}

Undang-Undang Republik Indonesia Nomor 8 Tahun 1995 tentang Pasar Modal.

Undang-Undang Republik Indonesia Nomor 21 Tahun 2011 tentang Otoritas Jasa Keuangan.

Peraturan Otoritas Jasa Keuangan Republik Indonesia Nomor 49/POJK.04/2016 tentang Dana Perlindungan Pemodal.

Peraturan Otoritas Jasa Keuangan Republik Indonesia Nomor 65/POJK.04/2020 tentang Pengembalian Keuntungan Tidak Sah dan Dana Kompensasi Kerugian Investor di Bidang Pasar Modal.

Surat Edaran Otoritas Jasa Keuangan Republik Indonesia Nomor 17/SEOJK.04/2021 tentang Pengembalian Keuntungan Tidak Sah dan Dana Kompensasi Kerugian Investor di Bidang Pasar Modal.

Rules of Practice and Rules on Fair Fund and Disgorgement Plans September 2019. 